\title{
FAKTOR-FAKTOR YANG MEMBERIKAN KONTRIBUSI TERHADAP KEPATUHAN WAJIB PAJAK OJEK ONLINE (OJOL) DI JAKARTA
}

\author{
Theressa Meiyanti \\ Mulyani* $^{*}$
}

Program Studi Akuntansi, Institut Bisnis dan Informatika Kwik Kian Gie, Jl. Yos Sudarso Kav 87 Jakarta 14350

\begin{abstract}
Tax is a mandatory contribution to the state that is owed by an individual or entity that is a force. Indonesian tax compliance level is still low shown by its low tax ratio. Motor Vehicles Tax is a tax on ownership or control of motorized vehicles. Taxpayer's compliance is taxpayers willingness to fulfill their tax obligations with respect to regulations. This research used quantitative hypothesis testing. The data and information were retrieved from questionnaire results filled in by 100 Gojek taxpayer drivers. This research used Likert scale, SPSS 20 software, Validity and Reliability, Classical Assumption Test, $F$-test, $t$-test, and $R^{2}$ test. Therefore, it can be concluded that taxpayer's knowledge and awareness have a positive effect on motorcycle taxpayer's compliance. However, there is no evidence that taxpayer's level of income has effects on motorcycle taxpayer's compliance.
\end{abstract}

Keywords : Taxpayer Compliance, Taxpayer Awareness, Taxpayer Knowledge, Taxpayer's Level of Income

\begin{abstract}
Abstrak
Pajak adalah kontribusi wajib kepada negara yang terutang oleh orang pribadi atau badan yang bersifat memaksa. Tingkat kepatuhan masyarakat Indonesia dalam membayar pajak masih rendah dilihat dari tax ratio yang masih rendah. Pajak kendaraan bermotor adalah pajak atas kepemilikan atau penguasaan kendaraan bermotor. Kepatuhan wajib pajak adalah wajib pajak mempunyai kesediaan untuk memenuhi kewajiban perpajakannya sesuai dengan aturan yang berlaku. Penelitian ini menggunakan uji hipotesis secara kuantitatif. Data dan informasi diperoleh dari hasil kuesioner yang diisi oleh 100 Wajib Pajak Pengendara Gojek. Penelitian ini menggunakan Skala Likert, Software SPSS 20, Uji Validitas dan Reliabilitas, Uji Asumsi Klasik, Uji F, Uji t, dan Uji R ${ }^{2}$. Dari hasil penelitian ini disimpulkan bahwa terbukti bahwa pengetahuan dan kesadaran wajib pajak berpengaruh positif terhadap kepatuhan wajib pajak kendaraan bermotor roda dua. Namun, tidak terdapat bukti bahwa tingkat pendapatan wajib pajak berpengaruh terhadap kepatuhan wajib pajak kendaraan bermotor roda dua.
\end{abstract}

Kata Kunci : Kepatuhan Wajib Pajak, Kesadaran Wajib Pajak, Pengetahuan Wajib Pajak, Tingkat Pendapatan Wajib Pajak

\section{Pendahuluan}

Secara terirorial, pajak dikelompokkan menjadi dua yaitu pajak pusat dan pajak daerah. Sesuai dengan Undang-undang Pajak Daerah dan Retribusi Daerah Nomor 28 Tahun 2009 Pajak Daerah adalah kontribusi wajib pajak kepada daerah yang terutang oleh orang pribadi atau badan yang bersifat memaksa dengan tidak mendapatkan imbalan secara langsung yang digunakan untuk keperluan daerah. Salah satu pajak daerah adalah Pajak Kendaraan Bermotor. Menurut Badan Pusat Statistik Provinsi DKI Jakarta, Pajak Kendaraan Bermotor yang memiliki jumlah wajib pajak yang paling banyak di antara jenis pajak daerah lainnya.

\footnotetext{
*Alamat kini: Institut Bisnis dan Informatika Kwik Kian Gie, Jl. Yos Sudarso Kav. 87, Jakarta 14350

Penulis untuk Korespondensi: Telp. (021) 65307062 Ext. 708, Email: mulyani@kwikkiangie.ac.id
} 
Penggunaan kendaraan bermotor roda dua yang tinggi di DKI Jakarta terlihat jelas dari padatnya kendaraan bermotor roda dua yang melintas di jalanan setiap hari. Pertumbuhan ekonomi DKI Jakarta saat ini, diwarnai oleh banyaknya warga DKI yang bekerja sebagai ojek online. Bisa jadi, kendaraan bermotor roda dua mudah dimiliki oleh semua kalangan. Selain itu, kemacetan menjadi faktor utama penyebab besarnya kebutuhan terhadap ojek online. Salah satu ojek online yang terkenal saat ini adalah Gojek. Menurut www.tribunnews.com, pengemudi Gojek saat ini mencapai lebih dari satu juta pengemudi. Sebagian besar pengendara Gojek merupakan pemilik kendaraan yang dipakainya untuk mencari penghasilan dan sudah semestinya sebagai wajib pajak atas kendaraan bermotor yang dimiliki. Kepemilikan itu terlihat dari salah satu syarat menjadi pengendara Gojek, yaitu nama pemilik dalam surat tanda nomor kendaraan (STNK) harus sama dengan surat izin mengemudi (SIM) dan kartu tanda penduduk (KTP) ataupun nama di STNK harus terdaftar pula di kartu keluarga (KK).

Kepatuhan wajib pajak merupakan salah satu keadaan dimana wajib pajak memenuhi semua kewajiban perpajakan. Berita Kompas.com, Direktur Penyuluhan Pelayanan dan Hubungan Masyarakat Direktorat Jenderal Pajak mengungkapkan bahwa saat ini tingkat kepatuhan masyarakat Indonesia dalam membayar pajak masih rendah. Tingkat kepatuhan pajak dapat dilihat dari tingkat tax ratio sebesar 10,3 persen. Sebanyak 44,6 persen pemilik kendaraan belum membayar pajak, tunggakan pajak kendaraan bermotor mencapai Rp 1,6 Triliun. Ini menunjukan masih banyak Wajib Pajak yang tidak patuh membayar pajak.

Beberapa faktor penyebab kepatuhan wajib pajak rendah adalah tingkat pengetahuan wajib pajak. Kesadaran wajib pajak dan pendapatan wajib pajak. Tingkat pengetahuan wajib pajak yang dimaksud adalah pengetahuan tentang pembayaran, penghitungan, dan pelaporan pajak. Pengetahuan wajib pajak dapat diperoleh dari pendidikan formal, pelatihan, maupun lewat sosialisasi. Semestinya, semakin mengerti wajib pajak terhadap pentingnya pajak bagi masyarakat dan negara maka semakin patuh pula wajib pajak untuk melakukan kewajiban membayar pajak. Faktanya, dalam beberapa kasus ditemukan bahwa pengetahuan wajib pajak yang baik justru semakin mencari cara untuk menghindari ataupun mengurangi jumlah pajak yang seharusnya mereka bayarkan. Hal ini sebagaimana yang disampaikan oleh Damajanti (2015), bahwa pengetahuan wajib pajak tidak berpengaruh terhadap kepatuhan wajib pajak. Namun dalam penelitian lain, Adiasa (2013) menyatakan bahwa pengetahuan wajib pajak berpengaruh positif terhadap kepatuhan wajib pajak.

Kesadaran wajib pajak. Menurut $C N N$ Indonesia, faktor lingkungan atau iklim yang musti dibangun untuk meningkatkan kesadaran wajib pajak untuk membayar pajak adalah dengan meningkatan kualitas layanan kesehatan, pendidikan, penyediaan infrastuktur yang memadai, kemudahan dunia usaha, kemudahan sistem perpajakan, dan sikap saling percaya antara wajib pajak dengan pihak fiskus. Dengan meningkatnya kualitas layanan publik diharapkan akan meningkatkan tingkat kesadaran wajib pajak. Dengan meningkatnya kesadaran wajib pajak diharapkan akan meningkatkan kepatuhan wajib pajak. Membangun iklim perpajakan yang baik diawali dengan meningkatkan kualitas layanan publik. Kesadaran Wajib Pajak menurut Rahayu (2017:191) merupakan kondisi dimana Wajib Pajak mengerti dan memahami arti, fungsi maupun tujuan pembayaran pajak kepada Negara. Dengan kesadaran Wajib Pajak yang tinggi akan memberikan pengaruh pada peningkatan kepatuhan pajak yang lebih baik lagi.Pendapatan wajib pajak. Sari dan Susanti (2013) menyatakan bahwa tingkat pendapatan akan mempengaruhi kepatuhan wajib pajak dalam membayar pajak. Kemampuan wajib pajak dalam memenuhi kewajiban pajak terkait erat dengan besarnya penghasilan wajib pajak. Selanjutnya, besarnya tingkat pendapatan akan menjadi pertimbangan dalam pemungutan pajak, sehingga jika persepsi wajib pajak terhadap tingkat penghasilannya semakin tinggi maka akan menjadi pertimbangan wajib pajak dalam memenuhi kewajiban perpajakannya, termasuk kewajiban dalam membayar pajak kendaraan bermotor.

Penelitian ini dimaksudkan untuk mengetahui pengaruh pengetahuan wajib pajak, kesadaran wajib pajak, dan tingkat pendapatan wajib pajak terhadap kepatuhan wajib pajak bagi pengendara kendaraan bermotor roda dua yang bergabung dalam ojek online Gojek (ojol gojek) di wilayah DKI Jakarta. 
Pengembangan Hipotesis

$\begin{array}{llll}\begin{array}{l}\text { Pengaruh } \\ \text { terhadap }\end{array} & \begin{array}{l}\text { Pengetahuan } \\ \text { Kepatuhan }\end{array} & \begin{array}{c}\text { Wajib } \\ \text { Wajib }\end{array} & \begin{array}{l}\text { Pajak } \\ \text { Pajak }\end{array} \\ \text { Kendaraan. } & & & \end{array}$

Pentingnya aspek pengetahuan perpajakan bagi wajib pajak ini sangat mempengaruhi sikap wajib pajak terhadap sistem perpajakan yang adil. Dengan kualitas pengetahuan yang semakin baik akan memberikan sikap memenuhi kewajiban dengan benar melalui adanya sistem perpajakan suatu negara yang dianggap adil (Kemala, 2015). Pengetahuan akan peraturan perpajakan masyarakat melalui pendidikan formal maupun nonformal akan berdampak positif terhadap kesadaran wajib pajak untuk membayar pajak karena pengetahuan perpajakan merupakan hal yang paling mendasar harus dimiliki wajib pajak (Yulianawati dan Hardiningsih, 2011). Hasil penelitian yang dilakukan oleh Susilawati dan Budhiarta (2013) disebutkan bahwa pengetahuan pajak wajib pajak secara parsial berpengaruh positif terhadap tingkat kepatuhan membayar pajak kendaraan bermotor.

Ha1 : Pengetahuan Wajib Pajak berpengaruh positif terhadap Kepatuhan Wajib Pajak Kendaraan Bermotor Roda Dua.

\section{Pengaruh Tingkat Kesadaran Wajib Pajak terhadap Kepatuhan Wajib Pajak}

Kesadaran wajib pajak merupakan sebuah itikad baik seseorang untuk memenuhi kewajiban membayar pajak berdasarkan hati nuraninya yang tulus ikhlas. Semakin tinggi tingkat kesadaran wajib pajak, maka pemahaman dan pelaksanaan kewajiban perpajakan semakin baik sehingga dapat meningkatkan kepatuhan menurut Susilawati dan Budiartha (2013). Hasil Penelitian Susilawati dan Budiartha (2013) dan Ilhamsyah dkk., (2016) menunjukan bahwa kesadaran wajib pajak mempunyai pengaruh yang signifikan terhadap kepatuhan wajib pajak.

Ha2: Kesadaran wajib pajak berpengaruh positif terhadap Kepatuhan Wajib Pajak Kendaraan Bermotor Roda Dua.

\section{Pengaruh Tingkat Pendapatan Wajib Pajak terhadap Kepatuhan Wajib Pajak}

Pendapatan wajib pajak adalah penghasilan yang diperoleh wajib pajak dari bekerja dan akhir bulan mendapatkan gaji.
Pendapatan merupakan tambahan kekayaan atau harta yang diperoleh baik dalam maupun dari luar negara yang dipungut untuk memenuhi kebutuhan hidupnya. Wajib pajak akan lebih memilih menggunakan pendapatannya untuk memnuhi kebutuhan hidupnya dari pada digunakan untuk membayar pajak.

Penelitian yang dilakukan oleh Sari dan Susanti (2013) mengatakan bahwa faktor yang mempengaruhi kepatuhan wajib pajak dalam membayar PKB dari faktor yang menempati posisi paling tinggi yaitu Pemahaman terhadap sistem pemungutan pajak, kualitas pelayanan, tingkat pendidikan, persepsi wajib pajak terhadap sanksi perpajakan, dan tingkat penghasilan.

Ha3 : Tingkat pendapatan wajib pajak berpengaruh positif terhadap Kepatuhan Wajib Pajak Kendaraan Bermotor Roda Dua.

\section{Metode Penelitian}

\section{Populasi dan Sampel Penelitian}

Populasi dalam penelitian ini adalah pengguna Gojek yang ada di Indonesia. Teknik pengambilan sampel menggunakan teknik accidental sampling. Teknik ini merupakan teknik penentuan sampel berdasarkan kebetulan, yaitu siapa saja yang secara kebetulan bertemu dengan peneliti dan dipandang cocok sebagai sumber data, maka dapat dijadikan sebagai sampel (Sugiyono, 2017:85). Ukuran sampel diambil berdasarkan metode yang di katakan oleh Roscoe (Sugiyono, 2017:91), yaitu bila dalam penelitian akan melakukan analisis dengan multivariate (korelasi atau regresi ganda), maka jumlah anggota sampel minimal 10 kali dari jumlah variabel yang diteliti. Pada penelitian ini ada 4 (independen + dependen), maka jumlah anggota sampel $=10 \times 4=40$. Agar data yang didapatkan lebih akurat lagi maka ditambahkan sampel menjadi 100 sampel. Sampel dari penelitian ini adalah pengguna Gojek yang ada di DKI Jakarta.

\section{Variabel Penelitian}

Variabel dependen yang digunakan dalam penelitian ini adalah kepatuhan wajib pajak kendaraan bermotor roda dua di DKI Jakarta. Variabel independen yang digunakan dalam penelitian ini adalah pengetahuan wajib pajak, 
kesadaran wajib pajak, dan tingkat pendapatan wajib pajak.

\section{Teknik Pengumpulan Data}

Menurut Cooper dan Schindler (2017), teknik pengumpulan data terdiri dari 2 yaitu teknik komunikasi dan observasi atau pengamatan. Pada penulisan skripsi ini penulis menggunakan teknik pengumpulan data komunikasi yang bertujuan mengolah beberapa karakteristik data seperti sikap, maksud, motivasi, dan harapan. Sedangkan instrumen yang digunakan adalah kuesioner yaitu teknik pengumpulan data dengan cara memberikan sejumlah pertanyaan tertulis yang disusun secara terstruktur kepada responden untuk dijawab

\section{Teknik Analisis Data}

Teknik analisis data yang digunakan oleh peneliti sebagai berikut

1. Uji Skala Likert

Skala likert (Sekaran dan Bougie, 2017:30) didesain untuk menelaah seberapa kuat subjek setuju atau tidak setuju dengan pernyataan yang diberikan. Respons terkait sejumlah poin yang menekankan konsep variabel tertentu dapat dianalisis per poin namun juga memungkinkan untuk menghitung total atau penjumlahan nilai untuk setiap responden dengan menjumlahkan antar poin.

2. Uji Kualitas Data

a. Uji Validitas, menurut Cooper dan Schindler (2017) menunjukan derajat ketepatan antara data yang sesungguhnya terjadi pada objek dengan data yang dikumpulkan oleh peneliti.

b. Uji Reliabilitas, berguna untuk menetapkan apakah instrumen yang dalam hal ini dapat digunakan lebih dari satu kali paling tidak oleh responden yang sama akan menghasilkan data yang konsisten. Dengan kata lain, reliabilitas instrumen mencirikan tingkat konsistensi.

3. Analisis Deskriptif

Metode deskriptif digunakan untuk menggambarkan mengenai fakta-fakta yang ada secara faktual dan sistematis.

4. Uji Asumsi Klasik

Uji asumsi klasik dilakukan untuk menguji kualitas data yang diregresikan. Uji asumsi klasik yang akan diujikan sebagai berikut a. Uji Normalitas,bertujuan untuk menguji apakah dalam sebuah model regresi, variabel independen, variabel dependen mempunyai distribusi normal atau tidak (Sekaran dan Bougie, 2017).

b. Uji Autokorelasi, bertujuan untuk mengetahui apakah dalam sebuah model regresi linier ada korelasi antara kesalahan pengganggu (Sekaran dan Bougie, 2017).

c. Uji heteroskedastisitas, bertujuan untuk menguji apakah dalam model regresi terjadi ketidaksamaan varians dari residual suatu pengamatan ke pengamatan yang lain.

d. Uji Multikolonieritas, bertujuan untuk menguji apakah model regresi ditemukan adanya korelasi antar variabel bebas (independent).

5. Analisis Linier Berganda

Persamaan regresi berganda di rumuskan :

KPWP $=\alpha+\beta_{1} \mathrm{PWP}+\beta_{2} \mathrm{KWP}+$ $\beta_{3} \mathrm{TPWP}+\varepsilon$

Keterangan :

KPWP = Kepatuhan Wajib Pajak

Kendaraan Bermotor Roda Dua

$\mathrm{PWP}=$ Pengetahuan Wajib Pajak

KWP $=$ Kesadaran Wajib Pajak

TPWP $=$ Tingkat Pendapatan Wajib

Pajak

$\alpha=$ Konstanta

$\beta=$ Koefisien regresi variabel

$\varepsilon=$ Koefisien error

6. Uji Hipotesis

a. Uji Kelayakan Model (Uji F), untuk menunjukkan pengaruh variabel independen terhadap variabel dependen.

b. Uji t, digunakan untuk menentukan apakah setiap variabel independen berpengaruh signifikan terhadap variabel dependen yang disusun.

c. Koefisien determinasi $\left(\mathrm{R}^{2}\right)$ mengukur seberapa jauh kemampuan model dalam menerangkan variasi variabel dependen.

\section{Hasil Penelitian dan Pembahasan}

\section{Hasil Penelitian \\ Uji Validitas}

Kriteria valid untuk setiap butir pertanyaan dari setiap variabel didasarkan pada nilai CITC (Corrected Item-Total Correlation) $\geq 0.361$, dan jika sebaliknya, maka butir pertanyaan dianggab tidak valid. Pada variabel 
independen pengetahuan wajib pajak terdapat pernyataan yang tidak valid yaitu pada indikator P6 karena nilai CITC pada indikator P6 menunjukkan angka $0,111<0,361$. Selain indikator P6, semua indikator pada variabel yang lainnya dinyatakan valid.

\section{Uji Reliabilitas}

Nilai Reliabilitas diukur dengan nilai Cronbach's Alpha $>0,60$. Jika nilai Cronbach's Alpha masing-masing variabel > 0,60 maka variabel tersebut dinyatakan reliabel. Semua pernyataan memiliki nilai Cronbach's Alpha > 0,60 . Hal ini menunjukkan bahwa setiap item pertanyaan yang digunakan akan mampu memperoleh data yang konsisten.

\section{Analisis Deskriptif}

Pada Tabel 3 kita dapat diketahui bahwa variabel pengetahuan wajib pajak memiliki nilai minimum responden sebesar 2 dan nilai maksimum responden sebesar 5. Rata-rata total jawaban sebesar 4.16 sehingga dapat dinyatakan bahwa pengetahuan wajib pajak para pengendara Gojek rata-rata tinggi. Selain itu ditunjukkan penyimpangan data yang kecil dikarenakan nilai standar deviasi sebesar 0.54 lebih kecil dari nilai rata-rata.

Variabel kesadaran wajib pajak memiliki nilai minimum responden sebesar 1 dan nilai maksimum responden sebesar 5. Rata-rata total jawaban sebesar 3.85 sehingga dapat disimpulkan bahwa kesadaran wajib pajak para pengendara Gojek rata-rata tinggi. Selain itu ditunjukkan penyimpangan data yang kecil dikarenakan nilai standar deviasi sebesar 0.72 lebih kecil dari nilai rata-rata.

Variabel pendapatan wajib pajak memiliki nilai minimum responden sebesar 2 dan nilai maksimum responden sebesar 5. Rata-rata total jawaban sebesar 3.74 sehingga dapat disimpulkan bahwa pengetahuan wajib pajak para pengendara Gojek rata-rata tinggi. Selain itu ditunjukkan penyimpangan data yang kecil dikarenakan nilai standar deviasi sebesar 0.58 lebih kecil dari nilai rata-rata.

Variabel kepatuhan wajib pajak kendaraan bermotor roda dua memiliki nilai minimum responden sebesar 1 dan nilai maksimum responden sebesar 5. Rata-rata total jawaban sebesar 4.07 sehingga dapat disimpulkan bahwa pengetahuan wajib pajak para pengendara Gojek rata-rata tinggi. Selain itu ditunjukkan penyimpangan data yang kecil dikarenakan nilai standar deviasi sebesar 0.67 lebih kecil dari nilai rata-rata.

\section{Uji Asumsi Klasik}

Uji Normalitas

Uji normalitas data penelitian ini menggunakan uji Kolmogorov-Smirnov dengan tingkat signifikansi lebih besar dari 5\%, maka dapat dikatakan bahwa variabel tersebut berdistribusi normal. Dari hasil uji normalitas dengan uji Kolmogorov-Smirnov pada Tabel 4 menunjukkan bahwa nilai signifikansi 0,143 . Nilai signifikansi tersebut lebih besar dari 0.05 sehingga menunjukkan bahwa data pada model tersebut berdistribusi normal.

\section{Uji Multikolinearitas}

Pada pengujian multikolinearitas menyatakan bahwa tidak terjadi multikolinearitas pada variabel independen pengetahuan, kesadaran, dan pendapatan terhadap variabel dependen kepatuhan wajib pajak kendaraan bermotor roda dua, karena hasil pengolahan data pada Tabel 5 menunjukkan angka pada masing-masing variabel yaitu nilai VIF $<10$ dan nilai Tolerance lebih dari 0,10 .

\section{Uji Heterokedastisitas}

Cara yang digunakan untuk mendeteksi heteroskedastisitas adalah dengan melihat Pola Gambar Scatterplots. Berdasarkan output scatterplot pada gambar 1 dapat dilihat bahwa

1. Titik-titik data penyebar di atas dan di bawah atau di sekitar angka 0 .

2. Titik-titik tidak mengumpul hanya di atas atau di bawah saja.

3. Penyebaran titik-titik data tidak boleh membentuk pola bergelombang melebar kemudian menyempit dan melebar kembali. 4. Penyebaran titik-titik data tidak berpola.

Dengan demikian dapat kita simpulkan bahwa tidak terjadi masalah heteroskedastisitas, sehingga model regresi yang baik dan ideal dapat terpenuhi.

\section{Uji Autokorelasi}

Hasil pengujian autokorelasi pada Tabel 6, dapat dinyatakan bahwa tidak terjadi autokorelasi pada variabel independen pengetahuan, kesadaran, dan pendapatan terhadap variabel dependen kepatuhan wajib pajak kendaraan bermotor roda dua, karena hasil dari pengolahan data menunjukkan angka Durbin-watson > 0,05 yaitu 2.071.

\section{Uji Hipotesis}

Uji F

Berdasarkan pada Tabel 7, hasil uji $\mathrm{F}$ dengan nilai sig sebesar $0,000^{\mathrm{b}}<0,05$ maka 
model persamaan regresi dapat digunakan karena terdapat hubungan variabel dependen kepatuhan wajib pajak kendaraan bermotor roda dua dengan variabel independen pengetahuan, kesadaran, dan pendapatan wajib pajak.

\section{Uji t}

Berdasarkan pada Tabel 8, nilai signifikan pada variabel pengetahuan (X1) sebesar 0,0045 $<0,05$ maka tolak Ho terima Ha sehingga terdapat pengaruh positif antara pengetahuan terhadap kepatuhan wajib pajak kendaraan bermotor roda dua $(\mathrm{Y})$. Kesadaran wajib pajak (X2) sebesar $0,000<0,05$ maka tolak Ho terima Ha sehingga terdapat pengaruh positif antara kesadaran wajib pajak (X2) terhadap kepatuhan wajib pajak kendaraan bermotor roda dua $(\mathrm{Y})$. Pendapatan wajib pajak (X3) sebesar 0,3865 > 0,05 maka terima Ho tolak Ha sehingga tidak terdapat pengaruh antara pendapatan wajib pajak (X3) terhadap kepatuhan wajib pajak kendaraan bermotor roda dua $(\mathrm{Y})$.

\section{Koefisien Determinasi}

Berdasarkan hasil pengujian pada Tabel 9, diketahui nilai koefisien determinasi (R Square) sebesar 0,265. Besarnya angka koefisien determinasi ( $\mathrm{R}$ Square) 0,265 sama dengan $26,5 \%$. Angka tersebut mengandung arti bahwa pengetahuan, kesadaran, dan pendapatan wajib dapat menerangkan kepatuhan wajib pajak kendaraan bermotor roda dua sebesar $26,5 \%$. Sedangkan sisanya $(100 \%-26,5 \%=74,5 \%)$ diterangkan oleh variabel lain di luar model regresi ini.

\section{Pembahasan}

\section{Pengaruh Pengetahuan Wajib Pajak Terhadap Kepatuhan Wajib Pajak Kendaraan Bermotor Roda Dua}

Berdasarkan hasil penelitian yang telah dilakukan oleh peneliti serta dengan melakukan pengolahan data atas data-data yang diperoleh peneliti, maka terbukti bahwa pengetahuan wajib pajak berpengaruh signifikan terhadap kepatuhan wajib pajak kendaraan bermotor roda dua. Dimana dapat dilihat dari hasil uji t dengan nilai signifikansi sebesar $0,0045<0,05$ yang berarti bahwa semakin tinggi tingkat pengetahuan yang dimiliki oleh wajib pajak kendaraan roda dua maka semakin tinggi pula kepatuhan pembayaran pajak kendaraan bermotor roda dua. Diketahui nilai koefisien pada variabel pengetahuan wajib pajak (X1) sebesar 0,345 dan bertanda positif. Hal ini menunjukkan bahwa terjadi kenaikan pada pengetahuan wajib pajak (X1) dalam satu satuan kepatuhan wajib pajak kendaraan bermotor roda dua dapat meningkatkan variabel kepatuhan wajib pajak kendaraan bermotor roda dua sebesar 0,345. Hasil penelitian ini menunjukkan bahwa variabel pengetahuan wajib pajak berpengaruh signifikan dan positif terhadap kepatuhan wajib pajak kendaraan roda dua, yang mendukung penelitian sebelumnya yang dilakukan oleh Chusaeri, Daiana, dan Afifudin (2017) yang menemukan bukti bahwa pemahaman dan pengetahuan wajib pajak berpengaruh terhadap kepatuhan wajib pajak.

\section{Pengaruh Kesadaran Wajib Pajak Terhadap Kepatuhan Wajib Pajak Kendaraan Bermotor Roda Dua}

Berdasarkan hasil penelitian yang telah dilakukan oleh peneliti serta dengan melakukan pengolahan data atas data-data yang diperoleh peneliti, maka terbukti bahwa kesadaran wajib pajak berpengaruh signifikan terhadap kepatuhan wajib pajak kendaraan bermotor roda dua. Dimana dapat dilihat dari hasil uji t dengan nilai signifikansi sebesar $0,000<0,05$ yang berarti bahwa semakin tinggi tingkat kesadaran yang dimiliki oleh wajib pajak kendaraan roda dua maka semakin tinggi pula kepatuhan pembayaran pajak kendaraan bermotor roda dua. Diketahui nilai koefisien pada variabel kesadaran wajib pajak (X2) sebesar 0,363 dan bertanda positif. Hal ini menunjukkan bahwa terjadi kenaikan pada kesadaran wajib pajak (X2) dalam satu satuan kepatuhan wajib pajak kendaraan bermotor roda dua dapat meningkatkan variabel kepatuhan wajib pajak kendaraan bermotor roda dua sebesar 0,363 Hasil penelitian ini menunjukkan bahwa variabel kesadaran wajib pajak berpengaruh signifikan dan positif terhadap kepatuhan wajib pajak kendaraan roda dua, yang mendukung penelitian sebelumnya yang dilakukan oleh Susilawati dan Budiartha (2013) dan Ilhamsyah dkk., (2016) menunjukan bahwa kesadaran wajib pajak mempunyai pengaruh yang signifikan terhadap kepatuhan wajib pajak.

\section{Pengaruh Pendapatan Wajib Pajak Terhadap Kepatuhan Wajib Pajak Kendaraan Bermotor Roda Dua}

Berdasarkan hasil penelitian yang telah dilakukan oleh penulis serta dengan melakukan pengolahan data atas data-data yang diperoleh 
peneliti, maka tidak terbukti bahwa pendapatan wajib pajak berpengaruh signifikan terhadap kepatuhan wajib pajak kendaraan bermotor roda dua. Dimana dapat dilihat dari hasil uji t dengan nilai signifikansi sebesar $0.3865>0,05$. Hal ini tidak sesuai dengan hipotesis yang dibuat. Diketahui nilai koefisien pada variabel pendapatan wajib pajak (X3) sebesar -0.036 dan bertanda negatif. Hal ini menunjukkan bahwa terjadi kenaikan pada pendapatan wajib pajak (X3) dalam satu satuan kepatuhan wajib pajak kendaraan bermotor roda dua dapat menurunkan variabel kepatuhan wajib pajak kendaraan bermotor roda dua sebesar -0.036 . Hasil penelitian ini menunjukkan bahwa variabel pendapatan wajib pajak tidak berpengaruh signifikan dan negatif terhadap kepatuhan wajib pajak kendaraan roda dua, dimana bertolak belakang dengan penelitian Sari dan Susanti (2013) yang dapat membuktikan bahwa faktor yang mempengaruhi kepatuhan wajib pajak dalam membayar PKB dari faktor yang menempati posisi paling tinggi yaitu pemahaman terhadap sistem pemungutan pajak, kualitas pelayanan, tingkat pendidikan, persepsi wajib pajak terhadap sanksi perpajakan, dan tingkat penghasilan. Pada penelitian yang dilakukan oleh Sari dan Susanti (2013) faktor penghasilan juga merupakan faktor yang paling terakhir dan paling rendah. Dan penelitian tersebut juga dilakukan lima tahun yang lalu. Jika pada saat ini pendapatan tidak lagi menjadi faktor yang dapat mempengaruhi kepatuhan wajib pajak kendaraan bermotor roda dua sesuai dengan pernyataan para responden yang menyatakan bahwa bagaimanapun kondisi keuangan mereka, mereka akan tetap membayar pajak karena pajak merupakan sesuatu yang dipaksakan oleh Negara.

\section{Kesimpulan dan Saran}

\section{Simpulan}

Setelah melakukan pengolahan data dan melakukan analisis, maka dapat disimpulkan pengetahuan dan kesadaran wajib pajak berpengaruh signifikan positif terhadap kepatuhan wajib pajak kendaraan roda dua di DKI Jakarta, sedangkan pendapatan wajib pajak tidak berpengaruh signifikan negatif terhadap kepatuhan wajib pajak kendaraan roda dua.

\section{Saran}

Bagi pemerintah DKI, berdasarkan simpulan hasil penelitian bahwa tingkat pengetahuan wajib pajak dan kesadaran wajib pajak terbukti berpengaruh terhadap kepatuhan wajib pajak kendaraan, maka perlu melakukan peningkatan sosialisasi tentang perpajakan baik pengetahuan maupun tingkat kesadaran pajak kepada para pengendara Gojek sehingga akan meningkatkan kepatuhan wajib pajak kendaraan.

Bagi peneliti selanjutnya, sebaiknya menggunakan wilayah penelitian yang lebih luas dan menambah variabel lainnya seperti fasilitas pembayaran pajak online, program SAMSAT Corner, struktur organisasi, proses bisnis dan teknologi informasi, manajemen sumber daya manusia, good governance, reformasi administrasi perpajakan, sehingga akan menjadi lebih luas factor-faktor yang dapat mempengaruhi tingkat kepatuhan wajib pajak.

\section{Daftar Pustaka}

Adiasa, Nirawan. ( 2013), Pengaruh Peraturan Pajak terhadap Kepatuhan Wajib Pajak dengan Moderating Preference Resiko, Accounting Analysis Journal 2 (3).

Budiartha, I. Ketut \& Ketut Evi Susilawati (2013), Pengaruh Kesadaran Wajib Pajak, Pengetahuan Pajak, Sanksi Perpajakan dan Akuntabilitas Pelayanan Publik Pada Kepatuhan Wajib Pajak Kendaraan Bermotor, E-Jurnal Akuntansi Universitas Udayana, Vol 4, No. 2, 345357

Damajanti, A. (2015), Pengaruh Pengetahuan terhadap Kepatuhan Wajib Pajak Perorangan di Kota Semarang, Jurnal Dinamika Sosial Budaya, 17(2), 12-28.

Donald R, C. S. (2017), Metodologi Penelitian Bisnis (12th ed.), Jakarta, Salemba Empat.

Gunadi. (2017), Panduan Komprehensif Pajak Penghasilan, Jakarta, Bee Media Indonesia.

Hardiningsih, P. dan Yulianawati, N. (2011), Faktor-faktor yang Mempengaruhi Kemauan Membayar Pajak, Dinamika Keuangan Dan Perbankan, 3(1), 126-142. 
Ilhamsyah, R, Endang, M,G.W, Dewantara, R.Y., (2016), Pengaruh Pemahaman Dan Pengetahuan Wajib Pajak Tentang Peraturan Perpajakan, Kesadaran Wajib Pajak, Kualitas Pelayanan, Dan Sanksi Perpajakan Terhadap Kepatuhan Wajib Pajak Kendaraan Bermotor (Studi SAMSAT Kota Malang, Jurnal Perpajakan (JEJAK) Vol 8 No.1, Universitas Brawijaya

Kemala, W. (2015). Pengaruh Kesadaran Wajib Pajak, Pengetahuan Pajak, Sikap Wajib Pajak dan Reformasi Administrasi Perpajakan Terhadap Kepatuhan Wajib Pajak Kendaraan Bermotor, Jom. Fekon, 2(1), 1-15.

Rahayu, S. K. (2017), Perpajakan Indonesia, Bandung, Rekayasa Sains.

Sari, R. A. V. Y., \& Susanti, N. (2014), FaktorFaktor Yang Mempengaruhi Kepatuhan Wajib Pajak Dalam Membayar Pajak
Kendaraan Bermotor ( PKB ) Di Unit Pelayanan Pendapatan Provinsi (UPPP) Kabupaten Seluma, Jurnal Ekombis Review, 2(1), 63-78.

Sekaran, U. R. B. (2017), Metode Penelitian untuk Bisnis (6th ed.), Jakarta, Salemba Empat.

Sugiyono. (2017), Metode Penelitian Kualitatif, Kuantitatif, dan $R \& D$, Bandung, Alfabeta.

Susilawati, Ketut Evi \& I Ketut Budiartha. (2013), Pengaruh Kesadaran Wajib Pajak, Pengetahuan Pajak, Sanksi Perpajak, dan Akuntabilitas Pelayanan Publik Pada Kepatuahan Wajib Pajak Kendaraan Bermotor, E-Jurnal Akuntansi Universitas Udayana, 4(2), 345-357.

Undang-Undang Republik Indonesia Nomor 28 Tahun 2009 Tentang Pajak Daerah dan Retribusi Daerah. 


\section{LAMPIRAN}

Tabel 1

Hasil Uji Validitas

Case Processing Summary

\begin{tabular}{|cc|c|c|}
\hline & & $\mathrm{N}$ & $\%$ \\
\hline \multirow{2}{*}{ Cases } & Valid & 30 & 100.0 \\
& Excluded $^{\mathrm{a}}$ & 0 & .0 \\
& Total & 30 & 100.0 \\
\hline
\end{tabular}

a. Listwise deletion based on all variables in the procedure.

\section{Variabel : Kepatuhan Wajib Pajak Kendaraan Bermotor Roda Dua} Item-Total Statistics

\begin{tabular}{|l|r|r|r|r|}
\hline & $\begin{array}{c}\text { Scale Mean if } \\
\text { Item Deleted }\end{array}$ & $\begin{array}{r}\text { Scale Variance } \\
\text { if Item Deleted }\end{array}$ & $\begin{array}{r}\text { Corrected Item- } \\
\text { Total Correlation }\end{array}$ & $\begin{array}{c}\text { Cronbach's } \\
\text { Alpha if Item } \\
\text { Deleted }\end{array}$ \\
\hline kepatuhan1 & 20.07 & 13.513 & .482 & .815 \\
kepatuhan2 & 20.13 & 13.844 & .408 & .826 \\
kepatuhan3 & 20.70 & 11.183 & .614 & .788 \\
kepatuhan4 & 20.93 & 9.720 & .775 & .747 \\
kepatuhan5 & 21.10 & 8.990 & .802 & .741 \\
kepatuhan6 & 20.23 & 13.426 & .505 & .812 \\
\hline
\end{tabular}

Variabel : Pengetahuan Wajib Pajak

Item-Total Statistics

\begin{tabular}{|l|r|r|r|r|}
\hline & $\begin{array}{c}\text { Scale Mean if } \\
\text { Item Deleted }\end{array}$ & $\begin{array}{r}\text { Scale Variance } \\
\text { if Item Deleted }\end{array}$ & $\begin{array}{c}\text { Corrected Item- } \\
\text { Total } \\
\text { Correlation }\end{array}$ & $\begin{array}{c}\text { Cronbach's } \\
\text { Alpha if Item } \\
\text { Deleted }\end{array}$ \\
\hline pengetahuan1 & 21.97 & 6.171 & .746 & .600 \\
pengetahuan2 & 21.43 & 9.426 & .792 & .654 \\
pengetahuan3 & 21.27 & 10.202 & .524 & .702 \\
pengetahuan4 & 21.23 & 9.495 & .594 & .679 \\
pengetahuan5 & 21.37 & 8.861 & .486 & .696 \\
pengetahuan6 & 21.73 & 10.409 & .111 & .822 \\
\hline
\end{tabular}


Variabel : Kesadaran Wajib Pajak

Item-Total Statistics

\begin{tabular}{|l|r|r|r|r|}
\hline & $\begin{array}{c}\text { Scale Mean if } \\
\text { Item Deleted }\end{array}$ & $\begin{array}{c}\text { Scale Variance } \\
\text { if Item Deleted }\end{array}$ & $\begin{array}{c}\text { Corrected Item- } \\
\text { Total } \\
\text { Correlation }\end{array}$ & $\begin{array}{c}\text { Cronbach's } \\
\text { Alpha if Item } \\
\text { Deleted }\end{array}$ \\
\hline kesadaran1 & 18.43 & 23.426 & .668 & .782 \\
kesadaran2 & 18.53 & 23.568 & .656 & .785 \\
kesadaran3 & 17.97 & 26.171 & .721 & .781 \\
kesadaran4 & 18.30 & 28.148 & .366 & .844 \\
kesadaran5 & 18.50 & 26.121 & .491 & .821 \\
kesadaran6 & 18.27 & 24.202 & .737 & .770 \\
\hline
\end{tabular}

Variabel : Pendapatan Wajib Pajak

Item-Total Statistics

\begin{tabular}{|l|r|r|r|r|}
\hline & $\begin{array}{c}\text { Scale Mean if } \\
\text { Item Deleted }\end{array}$ & $\begin{array}{r}\text { Scale Variance } \\
\text { if Item Deleted }\end{array}$ & $\begin{array}{c}\text { Corrected Item- } \\
\text { Total } \\
\text { Correlation }\end{array}$ & $\begin{array}{c}\text { Cronbach's } \\
\text { Alpha if Item } \\
\text { Deleted }\end{array}$ \\
\hline pendapatan1 & 19.67 & 13.678 & .409 & .713 \\
pendapatan2 & 19.63 & 14.171 & .410 & .714 \\
pendapatan3 & 19.70 & 13.528 & .605 & .675 \\
pendapatan4 & 19.73 & 13.099 & .504 & .689 \\
pendapatan5 & 21.00 & 11.103 & .528 & .682 \\
pendapatan6 & 20.93 & 11.513 & .462 & .707 \\
\hline
\end{tabular}


Tabel 2

Hasil Uji Reliabilitas

Case Processing Summary

\begin{tabular}{|c|c|c|c|}
\hline & $\mathrm{N}$ & $\%$ \\
\hline & Valid & 30 & 100.0 \\
\hline Cases & $\begin{array}{l}\text { Excluded } \\
\mathrm{a}\end{array}$ & 0 & .0 \\
\hline & Total & 30 & 100.0 \\
\hline
\end{tabular}

a. Listwise deletion based on all variables in the procedure.

Variabel : Kepatuhan

\section{Reliability Statistics}

\begin{tabular}{|r|r|}
\hline $\begin{array}{c}\text { Cronbach's } \\
\text { Alpha }\end{array}$ & N of Items \\
\hline .822 & 6 \\
\hline
\end{tabular}

Variabel : Pengetahuan

\section{Reliability Statistics}

\begin{tabular}{|r|r|}
\hline $\begin{array}{c}\text { Cronbach's } \\
\text { Alpha }\end{array}$ & $\begin{array}{c}\text { N of } \\
\text { Items }\end{array}$ \\
\hline .737 & 6 \\
\hline
\end{tabular}

Variabel : kesadaran

\section{Reliability Statistics}

\begin{tabular}{|r|r|}
\hline $\begin{array}{c}\text { Cronbach's } \\
\text { Alpha }\end{array}$ & N of ltems \\
\hline .827 & \\
\hline
\end{tabular}

Variabel : Pendapatan

Reliability Statistics

\begin{tabular}{|r|r|}
\hline $\begin{array}{c}\text { Cronbach's } \\
\text { Alpha }\end{array}$ & N of Items \\
\hline .734 & \\
\hline
\end{tabular}

Tabel 3

Hasil Analisis Deskriptif

Analisis Deskriftif

\begin{tabular}{|l|r|r|r|r|r|}
\hline & \multicolumn{1}{|c|}{ N } & Minimum & Maximum & Mean & $\begin{array}{c}\text { Std. } \\
\text { Deviation }\end{array}$ \\
\hline RTPATUH & 100 & 1 & 5.00 & 4.0750 & .67018 \\
RTPH & 100 & 2 & 5.00 & 4.1660 & .54905 \\
RTKD & 100 & 1 & 5.00 & 3.8517 & .72702 \\
RTPD & 100 & 2 & 5.00 & 3.7433 & .58384 \\
Valid N & 100 & & & & \\
(listwise) & & & & & \\
\hline
\end{tabular}


Tabel 4

Hasil Uji Asumsi Klasik

Uji Normalitas

\begin{tabular}{|c|c|c|}
\hline & & $\begin{array}{l}\text { Unstandardized } \\
\text { Residual }\end{array}$ \\
\hline $\begin{array}{l}\text { N } \\
\text { Normal Parameters }{ }^{\mathrm{a}, \mathrm{b}} \\
\text { Most Extreme Differences } \\
\text { Kolmogorov-Smirnov Z } \\
\text { Asymp. Sig. (2-tailed) }\end{array}$ & $\begin{array}{l}\text { Mean } \\
\text { Std. Deviation } \\
\text { Absolute } \\
\text { Positive } \\
\text { Negative }\end{array}$ & $\begin{array}{r}100 \\
0 \mathrm{E}-7 \\
.57443813 \\
.115 \\
.068 \\
-.115 \\
1.149 \\
.143\end{array}$ \\
\hline
\end{tabular}

a. Test distribution is Normal.

b. Calculated from data.

Tabel 5

Uji Multikolinearitas

Coefficients $^{a}$

\begin{tabular}{|c|c|c|c|c|c|c|c|}
\hline \multirow[t]{2}{*}{ Model } & \multicolumn{2}{|c|}{$\begin{array}{l}\text { Unstandardized } \\
\text { Coefficients }\end{array}$} & \multirow{2}{*}{$\begin{array}{c}\text { Standardized } \\
\text { Coefficients } \\
\text { Beta }\end{array}$} & \multirow[t]{2}{*}{$t$} & \multirow[t]{2}{*}{ Sig. } & \multicolumn{2}{|c|}{$\begin{array}{l}\text { Collinearity } \\
\text { Statistics }\end{array}$} \\
\hline & $B$ & Std. Error & & & & $\begin{array}{c}\text { Toleranc } \\
\mathrm{e}\end{array}$ & VIF \\
\hline (Constant & 1.377 & .510 & & 2.703 & .008 & & \\
\hline RTPH & .345 & .129 & .282 & 2.674 & .009 & .687 & 1.456 \\
\hline RTKD & .363 & .086 & .394 & 4.243 & .000 & .888 & 1.126 \\
\hline RTPD & -.036 & .125 & -.032 & -.290 & .773 & .641 & 1.561 \\
\hline
\end{tabular}

a. Dependent Variable: RTPATUH

Tabel 6

Uji Autokorelasi

Model Summary

\begin{tabular}{|l|r|r|r|r|r|}
\hline Model & \multicolumn{1}{|c|}{$\mathrm{R}$} & R Square & \multicolumn{1}{|c|}{$\begin{array}{c}\text { Adjusted R } \\
\text { Square }\end{array}$} & $\begin{array}{c}\text { Std. Error of the } \\
\text { Estimate }\end{array}$ & Durbin-Watson \\
\hline 1 & $.515^{\mathrm{a}}$ & .265 & .242 & .58334 & 2.071 \\
\hline
\end{tabular}

a. Predictors: (Constant), RTPD, RTKD, RTPH

b. Dependent Variable: RTPATUH 
Tabel 7

Hasil Uji Kelayakan Model (Uji F) ANOVA $^{\mathrm{a}}$

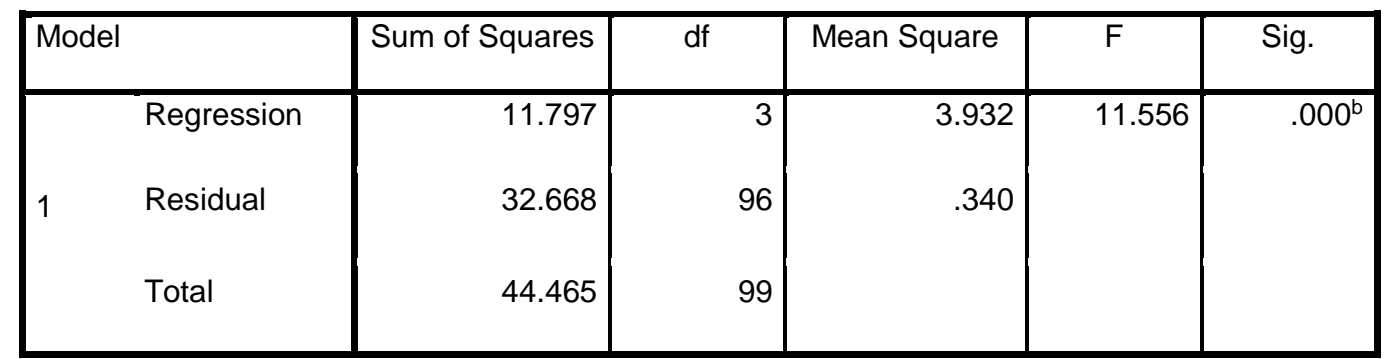

a. Dependent Variable: RTPATUH

b. Predictors: (Constant), RTPD, RTKD, RTPH

Tabel 8

Hasil Uji Hipotesis (Uji t)

Coefficients $^{\mathrm{a}}$

\begin{tabular}{|c|c|c|c|c|c|}
\hline \multirow[t]{2}{*}{ Model } & \multicolumn{2}{|c|}{ Unstandardized Coefficients } & \multirow{2}{*}{$\begin{array}{c}\text { Standardized } \\
\text { Coefficients }\end{array}$} & \multirow[t]{2}{*}{$\mathrm{t}$} & \multirow[t]{2}{*}{ Sig. } \\
\hline & $B$ & Std. Error & & & \\
\hline (Constant) & 1.377 & .510 & & 2.703 & .008 \\
\hline RTPH & .345 & .129 & .282 & 2.674 & .009 \\
\hline RTKD & .363 & .086 & .394 & 4.243 & .000 \\
\hline RTPD & -.036 & .125 & -.032 & -.290 & .773 \\
\hline
\end{tabular}

a. Dependent Variable: RTPATUH

Tabel 9

Hasil Uji Koefisien Determinasi $\left(\mathbf{R}^{2}\right)$ Model Summary

\begin{tabular}{|l|r|r|r|r|}
\hline Model & $\mathrm{R}$ & $\mathrm{R}$ Square & \multicolumn{1}{|c|}{$\begin{array}{c}\text { Adjusted R } \\
\text { Square }\end{array}$} & $\begin{array}{l}\text { Std. Error of the } \\
\text { Estimate }\end{array}$ \\
\hline 1 & $.515^{\mathrm{a}}$ & .265 & .242 & .58334 \\
\hline
\end{tabular}

a. Predictors: (Constant), RTPD, RTKD, RTPH 


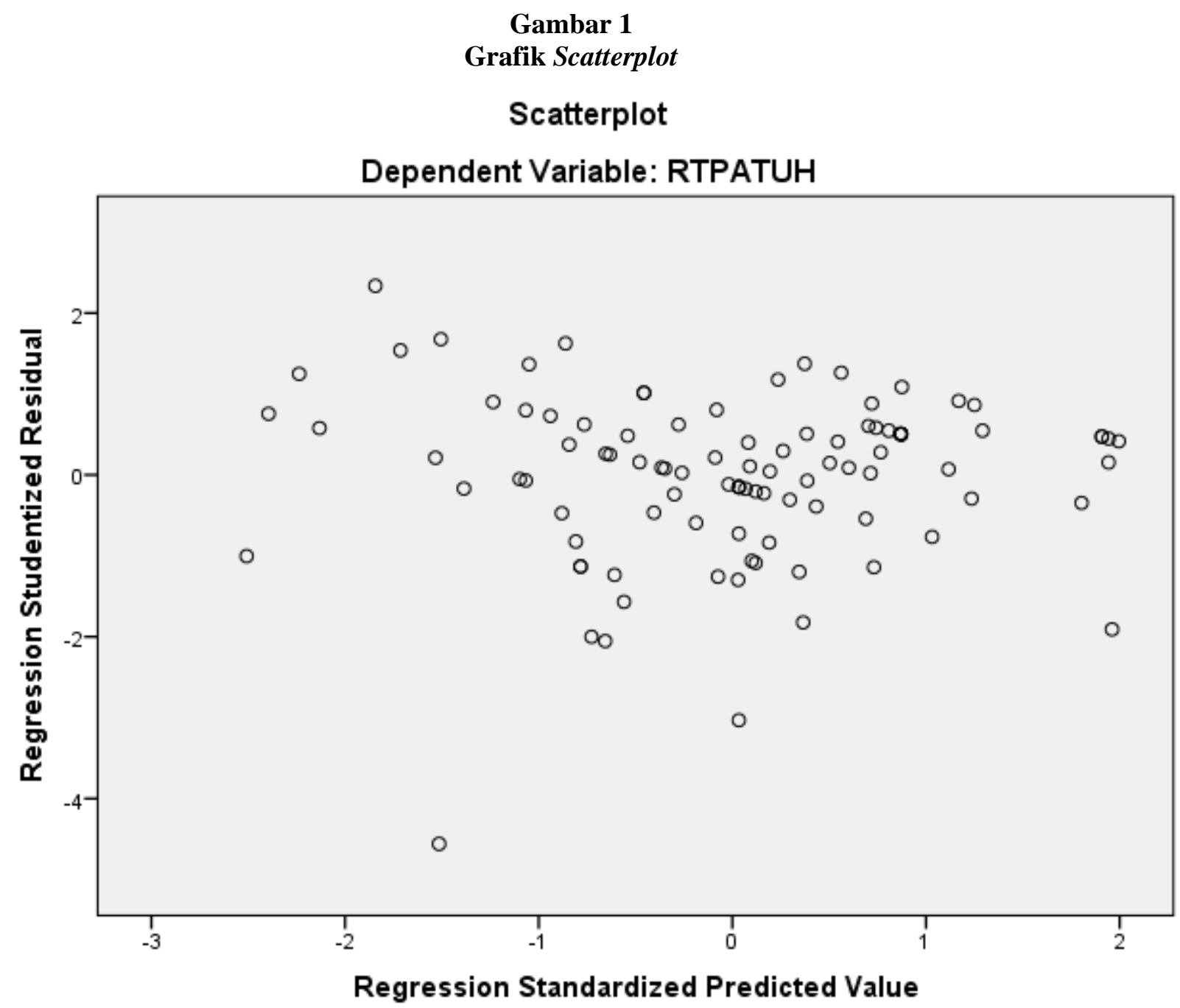

